\title{
Tingkat Serangan dan Kehilangan Hasil Akibat Penyakit Grasserie pada Sentra
}

\section{Persuteraan Alam Sulawesi Selatan}

\author{
Sitti Nuraeni' ${ }^{1}$, Astuti Arif', Edwin NL² \\ ${ }^{1}$ Fakultas Kehutanan Universitas Hasanuddin, Makassar Jl. Perintis Kemerdekaan Km 10 \\ Tamalanrea 90245 \\ 2Dinas Kehutanan Kabupaten Bantaeng \\ *E-mail: nuraenisitti@gmail.com
}

\begin{abstract}
Grasserie disease is one of the serious diseases caused by viruses. Its symptoms generally appear in the last instar of silkworm larvae or just before the formation of the cocoon. This study aimed to determine the level of attack, yield losses and dispersal patterns of grasserie at three sericulture center in South Sulawesi, Districs (Wajo, Soppeng and Enrekang). At each location 10 farmers were selected purposively as respondents. Direct observation was conducted to the farmer's rearing rack (on farmer's rearing bed) of silkworm using five replications. The results showed that the attack rates of grasserie were categorrised as very slight, ranging from 3.06 to $3.72 \mathrm{kgs}$ of yield losses per each box with a uniform pattern of disease spread. Reared of silkworms in accordance with standard operating procedures can reduce the rate of grasserie disease to avoid losing larger cocoon yields. Without preventive grasserie control, it can cause loss of cocoon yield in each maintenance period which will eventually cause farmers interest to sericulture decreasing
\end{abstract}

Keywords: Attack rate, loss of yield, grasserie, silkworm

DOI: http://dx.doi.org/10.24259/jhm.v10i2.4335

\section{PENDAHULUAN}

Provinsi Sulawesi Selatan merupakan daerah produsen sutera terbesar di Indonesia yaitu sekitar $80 \%$ dari total produksi Indonesia. Terdapat tiga kabupaten utama di Sulawesi Selatan yang menjadi sentra produksi kegiatan persuteraan alam, yaitu kabupaten Enrekang, Soppeng dan Wajo. Namun perkembangannya mulai mengalami pasang surut yang disebabkan oleh penurunan produksi kokon. Salah satu penyebab menurunnya produksi kokon adalah karena serangan patogen yang menyebabkan berbagai penyakit pada larva.

Penyakit ulatsutera merupakan faktor utama dan serius yang memengaruhi produksi kokon (Watanabe, 1986; Potrich, et al. 2007). Beberapa penyakit yang dapat menyerang pada ulatsutera yaitu grasserie, flacherie, muscardine dan pebrin yang masing-masing disebabkan oleh virus, bacteria, cendawan and microsporidia (Jiang and Xia, 2014). Selain penyakit pebrin yang disebabkan oleh Nosema bombycis, penyakit serius yang dapat menyerang ulatsutera adalah penyakit Bombyx mori Nuklear Polyhedrosis Virus (BmNPV) atau penyakit grasserie yang disebabkan oleh virus. Persuteraan alam global selalu dilaporkan adanya serangan penyakit virus BmNPV atau yang lebih dikenal sebagai penyakit graseria. Ulatsutera yang terserang akan mati di rak pemeliharaan atau pada alat pengokonan. Ulat yang mati akan pecah mengeluarkan cairan putih susu seperti nanah, sehinnga di Sulawesi Selatan penyakit BmNPV lebih dikenal sebagai penyakit nanah. Penyakit grasserie merupakan penyakit yang paling merugikan setelah penyakit pebrin di negara tropis (Chakrabarty et al., 2012) dan bahkan menjadi ancaman umum bagi serikultur di hampir semua negara penghasil sutera (Jiang dan Xia, 2014). 
Kerugian atau kegagalan panen kokon karena penyakit pada larva ulatsutera akan memberi dampak psikologis petani sehingga banyak yang beralih ke komoditi lain. Menurut Guo-Ping dan Xi-Jie (2011), fenomena kegagalan produksi karena serangan penyakit akan berdampak signifikan terhadap stabilitas serikultur dan juga pada animo masyarakat, sehingga studi tentang patologi ulatsutera dan penelitian terapan menjadi sangat penting. Berdasarkan hal tersebut, penelitian ini bertujuan mempelajari tingkat serangan grasserie, memformulasi tingkat kehilangan hasil akibat serangan BmNPV dan pola penyebarannya pada tiga kabupaten sentra pemeliharaan ulatsutera di Sulawesi Selatan.

\section{METODE PENELITIAN}

\subsection{Waktu dan Tempat}

Pengambilan sampel dilakukan pada tiga kabupaten, yaitu di Kecamatan Alla Kabupaten Enrekang

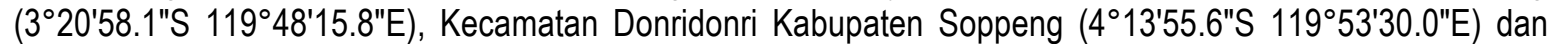

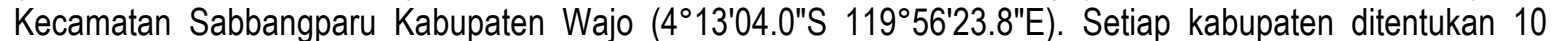
sampel petani sehingga jumlah seluruhnya 30 petani. Petani yang menjadi sampel adalah petani yang memelihara ulatsutera dengan jenis bibit dari Perum Perhutani Kabupaten Soppeng. Penghitungan ulat yang sakit diamati pada instar IV - V yang dilakukan pada rak pemeliharaan petani. Penentuan sampel ulat yang sakit dilakukan pada 5 plot pengamatan dalam satu rak pemeliharaan.

\subsection{Analisis Data}

Tingkat serangan penyakit grasserie, dihitung dengan menggunakan rumus sebagai berikut $T s=n / N x$ $100 \%$; $n$ adalah jumlah ulat yang terserang dan $\mathrm{N}$ adalah jumlah ulat yang diamati. Kategori tingkat serangan ditentukan sebagai berikut: Kategori serangan sangat ringan jika $\mathrm{T} \leq 10 \%$, serangan ringan jika $11 \% \leq \mathrm{T} \leq$ $30 \%$, serangan sedang jika $31 \% \leq \mathrm{T} \leq 50 \%$, serangan berat jika $51 \% \leq \mathrm{T} \leq 70 \%$, serangan sangat berat jika $71 \% \leq \mathrm{T} \leq 90 \%$ dan gagal panen jika $\mathrm{T} \geq 91 \%$. Perhitungan kehilangan hasil diasumsikan sebagai berikut : $\mathrm{Kh}=\mathrm{aT} / \mathrm{b}$, dimana $\mathrm{T}$ adalah Tingkat Serangan Penyakit grasserie, a adalah jumlah telur sebanyak 25.000 butir (boks), b adalah rata-rata jumlah kokon dalam $1 \mathrm{~kg}$.

Pola penyebaran penyakit grasserie pada ulatsutera dihitung dengan menggunakan Indeks Morisita atau yang biasa disebut ai-delta (Iठ) (Pielou, 1977) sebagai berikut:

$\delta=\frac{\sum_{i=1}^{N} n i(n i-1)}{n(n-1)} N$

Dimana: $\mathrm{N}=$ jumlah plot sampel, $\mathrm{ni}=$ jumlah individu sakit dalam plot sampel ke-i, $\mathrm{n}=$ jumlah total individu dalam plot sampel. Penetapan pola sebaran dengan cara menguji nilai $I \delta$; jika $I \delta=1$, maka pola penyebaran individu adalah acak, $\delta \delta>1$, maka pola penyebaran individu adalah mengelompok, $I \delta<1$, maka populasi memiliki pola penyebaran teratur/seragam (uniform).

\section{HASIL DAN PEMBAHASAN}

\subsection{Tingkat Serangan grasserie dan Kehilangan Hasil}

Tingkat serangan grasserie di tiga kabupaten sentra pemeliharaan ulatsutera di Sulawesi Selatan (Gambar 1), termasuk kategori sangat ringan, yaitu hanya berkisar 7,66-9,29\% atau di bawah $10 \%$. Kategori ini ditetapkan berdasarkan nilai pengorbanan petani memelihara ulatsuteranya sampai akhir instar V. Gejala penyakit graseria akan lebih jelas dan parah pada akhir instar $\mathrm{V}$ atau hendak mengokon. 


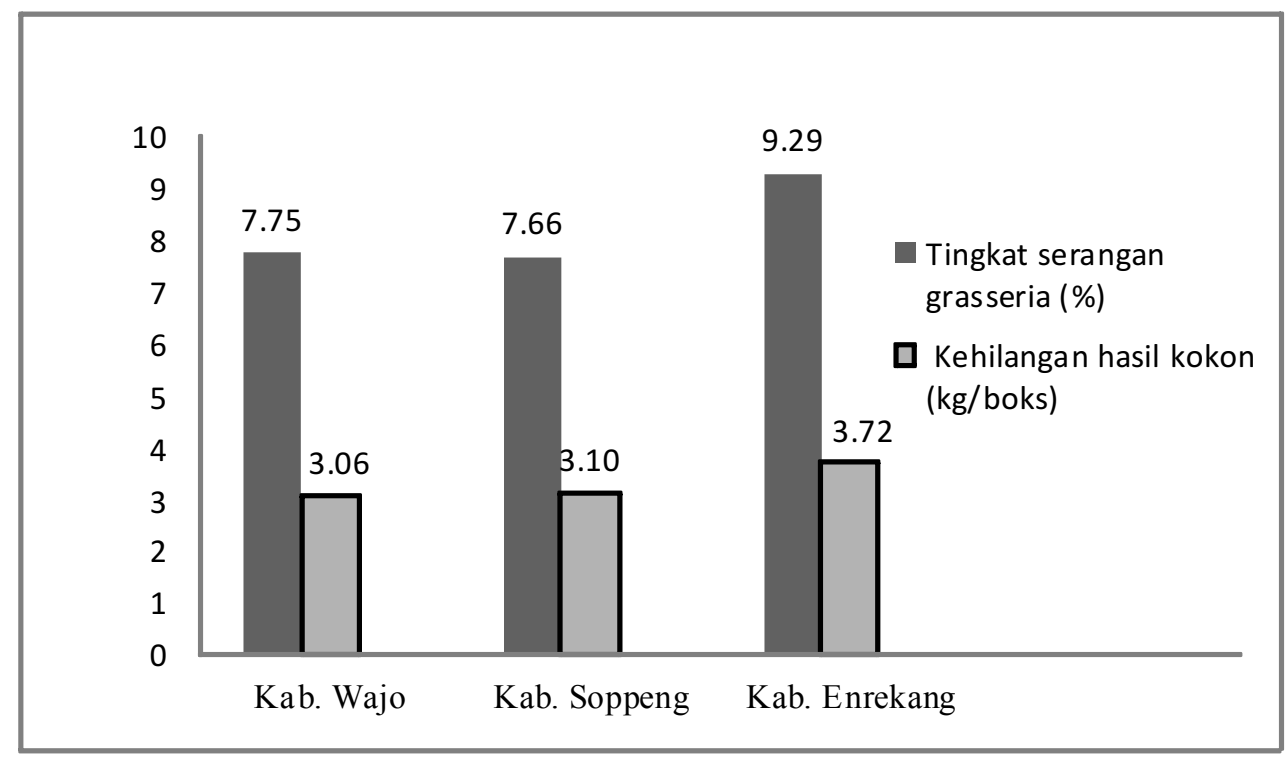

Gambar 1. Tingkat serangan grasserie dan kehilangan hasil kokon di tiga kabupaten sentra pemeliharaan ulatsutera di Sulawesi Selatan.

Persuteraan alam global mengalami kehilangan hasil kokon lebih dari 50\% akibat grasserie (Subbaiah et al., 2012; Gani et al., 2017) atau sekitar $70-80 \%$ dari total kehilangan hasil (Yup-lian, 1991; Babu et al., 2005; Jiang and Xia, 2014). Grasserie merupakan salah satu penyakit ulatsutera yang paling merugikan di Asia Tenggara, termasuk Indonesia dan Vietnam. Pada tiap periode pemeliharaan ulatsutera tidak luput dari serangan penyakit tersebut. Intensitas serangan NPV pada sentra-sentra pemeliharaan ulatsutera di Sulawesi Selatan dapat mencapai 42,5 - 73,9\% bahkan dapat menggagalkan total produksi kokon yang akan di panen (Anwar, 1985). Di Thailand dilaporkan tingkat serangan penyakit grasserie $30-100 \%$ (Kaewwises, 2006). Di India tingkat serangan penyakit graseria pada sentra pemeliharaan Barat Tamil Nadu berkisaar 4,04-31,58\% (Mahalingam et al, 2010).

Meskipun ketiga sentra pemeliharaan ulatsutera tingkat serangan grasserie termasuk kategori sangat ringan akan tetapi di Kabupaten Enrekang tingkat serangannya yang tertinggi. Rata-rata petani di Kabupaten Enrekang memberi makan ulatsuteranya hanya 2 atau 3 kali saja dalam sehari dibandingkan dua kabupaten lainnya. Asupan nutrisi dari daun murbei pada fase larva ulatsutera selain memengaruhi produktivitas kokon juga akan memengaruhi kerentanan terhadap penyakit. Menurut Watanabe (2002), Ada beberapa bukti bahwa ulatsutera membutuhkan kecukupan daun murbei dengan kualitas yang baik untuk melawan kerentanan terhadap infeksi polihedral virus. Sedangkan menurut Sharma et al. (2014) dan Mishra (2017), ulatsutera rentan terhadap penyakit grasserie apabila kondisi suhu dan kelembaban tinggi disertai kualitas daun murbei yang buruk.

Besarnya kehilangan hasil atau produksi kokon tergantung pada tingkat serangan grasserie, rata-rata berat kokon segar dari hasil pemeliharaan untuk menentukan jumlah kokon per $\mathrm{kg}$. Berat kokon petani ratarata 1,6 g/butir kokon sehingga dibutuhkan 625 butir kokon untuk $1 \mathrm{~kg}$. Tingkat serangan grasserie cenderung berkorelasi positif terhadap kehilangan hasil kokon $(\mathrm{kg})$. Di Indian kehilangan hasil akibat penyakit ini dapat mencapai 30,05 kg/100 dfls dengan berat kokon segarnya $1.74 \mathrm{~g}$ (Mahalingam et al, 2010). Rata-rata berat kokon India lebih berat dibandingkan hasil pemeliharaan dari ketiga sentra pemeliharaan di Sulawesi Selatan. Berat $1 \mathrm{~kg}$ di India hanya membutuhkan 575 butir dari berat rata-rata kokon segar $1.74 \mathrm{~g}$. Satuan bibit ulatsutera India adalah $100 \mathrm{dfls}$ (disease free layers, 1dfls $=1$ induk, $100 \mathrm{dfls}= \pm 50.000$ telur atau $=2$ boks Indonesia). Kehilangan hasil di Kabupaten Enrekang dapat mencapai 3,716 kg/boks (dari hasil perhitungan 
$9,29 \% \times 25.000$ (boks) dibagi 625 (butir kokon/kg)). Angka kehilangan ini 7,43 kg/2 boks lebih rendah dibandingkan kehilangan hasil di India $30,05 \mathrm{~kg} / 100$ dfls. Jika dirupiahkan kehilangan kokon dengan penawaran tertinggi kokon segar adalah Rp. 45.000,-/kg, maka didapatkan sebesar Rp.137.700 Rp.167.400,--

Tabel 1. Asal bibit, perlakuan dan faktor lingkungan pada ketiga sentra pemeliharaan ulatsutera.

\begin{tabular}{|c|c|c|c|c|c|c|}
\hline $\begin{array}{c}\text { Sentra } \\
\text { Pemeliharaan } \\
\text { Ulatsutera }\end{array}$ & $\begin{array}{l}\text { Skala } \\
\text { Usaha } \\
\text { (boks) }\end{array}$ & $\begin{array}{c}\text { Frekwensi } \\
\text { Pemberian } \\
\text { Pakan }\end{array}$ & Suhu $\left({ }^{\circ} \mathrm{C}\right)$ & $\begin{array}{c}\text { Kelembaban } \\
(\%)\end{array}$ & $\begin{array}{l}\text { Ketinggian } \\
\text { (mdpl) }\end{array}$ & $\begin{array}{l}\text { Persentase } \\
\text { Responden } \\
\text { Melakukan } \\
\text { Desinfeksi }\end{array}$ \\
\hline Kab. Wajo & $0,25-1$ & 3-4 kali & $28,5 \pm 0,5$ & $70 \pm 10$ & $65-100$ & $50 \%$ \\
\hline Kab. Soppeng & $\begin{array}{l}0,25- \\
1,25\end{array}$ & 3-4 kali & $30,5 \pm 2,5$ & $60 \pm 10$ & $80-120$ & $100 \%$ \\
\hline Kab. Enrekang & $1-1,5$ & 2-3 kali & $25,0 \pm 2,0$ & $90,5 \pm 0,5$ & $600-800$ & $100 \%$ \\
\hline
\end{tabular}

Pemeliharaan ulatsutera di Kabupaten Enrekang umumnya berada pada daerah ketinggian lebih dari $500 \mathrm{mdpl}$ (Tabel 1) yang berkorelasi negatif dengan suhu harian. Suhu udara di daerah ini lebih sesuai untuk kebutuhan pertumbuhan dan perkembangan ulatsutera. Menurut Watanabe (2002), suhu adalah faktor fisik eksternal yang paling penting yang menjadi faktor kedua terhadap kerentanan dan perbanyakan virus dalam tubuh inang. Kebanyakan varietas ulatsutera telah beradaptasi pada $25^{\circ} \mathrm{C}$. Suhu yang lebih tinggi atau lebih rendah dari $25{ }^{\circ} \mathrm{C}$ cenderung memicu stres dan meningkatkan kerentanan larva terhadap infeksi virus. Pemberian makan yang cukup bagi ulatsutera adalah faktor langsung yang lebih penting untuk pertahanan terhadap infeksi penyakit dibandingkan faktor lain termasuk suhu. Suhu di Kabupaten Wajo dan Soppeng lebih tinggi dibandingkan di Kabupaten Enrekang namun karena frekwesi pemberian daun murbei lebih sering sehingga kualitas pakan yang segar tetap terjaga.

Petani di Kabupaten Wajo hanya menggunakan kapur dan sebagian saja yang mencapur kapur dengan kaporit $\left(\mathrm{Ca}(\mathrm{ClO})_{2}\right)$ untuk desinfeksi larva pada saat selasai ganti kulit (ekdisis). Dengan demikian pemberian makan berupa daun murbei yang cukup dan segar merupakan hal yang penting untuk pertahanan dari infeksi virus. Menurut Andikarya (2007), keberhasilan pemeliharaan ulatsutera 38\% ditentukan oleh kuantitas dan kualitas pakan murbei.

\subsection{Pola Penyebaran Grasserie}

Pola penyebaran grasserie di tiga kabupaten sentra pemeliharaan ulatsutera di Sulawesi Selatan (Tabel 2), menunjukkan nilai $I \delta<1$, yaitu berkisar $0,0062-0,009$ yang berarti pola penyebarannya secara seragam. Pola penyebaran grasserie yang seragam atau teratur pada rak-rak pemeliharaan petani menunjukkan adanya perlakuan yang merata pada saat pemberian makan dan desinfeksi. Demikian pula halnya perlakuan perluasan ruang mikro (spacing) yang sesuai kebutuhan larva sehingga tingkat kepadatan larva di atas rak pemeliharaan seragam. Menurut Atmosoedarjo et al (2000), kebutuhan luas tempat atau rak pemeliharaan untuk larva instar V mencapai $16 \mathrm{~m}^{2}$. Luasan yang sesuai akan dapat menjaga suhu dan kelembaban sekitaran larva stabil sehingga tidak memberikan kesempatan patogen berkembang. 
Tabel 2. Pola penyebaran grasserie di tiga kabupaten sentra pemeliharaan ulatsutera di Sulawesi Selatan.

\begin{tabular}{|c|c|c|c|c|c|c|c|c|}
\hline Lokasi & Responden (N) & $\begin{array}{c}\text { Jumlah } \\
\text { larva } \\
\text { sakit per } \\
\text { plot (ni) }\end{array}$ & $(n i-1)$ & ni(ni-1) & $\sum$ ni(ni-1) & $\begin{array}{c}\Sigma \text { Ulat } \\
\text { yang } \\
\text { diamati } \\
\text { dalam plot } \\
(\mathrm{n})\end{array}$ & $\delta$ & $\begin{array}{c}\text { Pola } \\
\text { Penyebaran }\end{array}$ \\
\hline \multirow{10}{*}{ Wajo } & 1 & 42 & 41 & 1722 & \multirow{10}{*}{6832} & \multirow{10}{*}{3172} & \multirow{10}{*}{0,0066} & \multirow{10}{*}{ seragam } \\
\hline & 2 & 30 & 29 & 870 & & & & \\
\hline & 3 & 28 & 27 & 756 & & & & \\
\hline & 4 & 39 & 38 & 1482 & & & & \\
\hline & 5 & 18 & 17 & 306 & & & & \\
\hline & 6 & 21 & 20 & 420 & & & & \\
\hline & 7 & 23 & 22 & 506 & & & & \\
\hline & 8 & 11 & 10 & 110 & & & & \\
\hline & 9 & 21 & 20 & 420 & & & & \\
\hline & 10 & 16 & 15 & 240 & & & & \\
\hline \multirow{10}{*}{ Soppeng } & 1 & 28 & 27 & 756 & \multirow{10}{*}{4450} & \multirow{10}{*}{2665} & \multirow{10}{*}{0,0062} & \multirow{10}{*}{ seragam } \\
\hline & 2 & 18 & 17 & 306 & & & & \\
\hline & 3 & 23 & 22 & 506 & & & & \\
\hline & 4 & 34 & 33 & 1332 & & & & \\
\hline & 5 & 16 & 15 & 240 & & & & \\
\hline & 6 & 14 & 13 & 182 & & & & \\
\hline & 7 & 19 & 18 & 342 & & & & \\
\hline & 8 & 15 & 14 & 210 & & & & \\
\hline & 9 & 21 & 20 & 420 & & & & \\
\hline & 10 & 13 & 12 & 156 & & & & \\
\hline \multirow{10}{*}{ Enrekang } & 1 & 42 & 41 & 1722 & \multirow{10}{*}{18964} & \multirow{10}{*}{4588} & \multirow{10}{*}{0,009} & \multirow{10}{*}{ seragam } \\
\hline & 2 & 43 & 42 & 1806 & & & & \\
\hline & 3 & 33 & 32 & 1056 & & & & \\
\hline & 4 & 36 & 35 & 1260 & & & & \\
\hline & 5 & 39 & 38 & 1482 & & & & \\
\hline & 6 & 47 & 46 & 2162 & & & & \\
\hline & 7 & 28 & 27 & 756 & & & & \\
\hline & 8 & 32 & 31 & 992 & & & & \\
\hline & 9 & 58 & 57 & 3306 & & & & \\
\hline & 10 & 67 & 66 & 4422 & & & & \\
\hline
\end{tabular}

Pada tingkat petani, pola penyebaran penyakit seragam terjadi karena umumnya menggunakan bibit ulatsutera yang sama. Informasi pola-pola penyebaran penyakit ini akan bermanfaat untuk mengetahui titiktitik mana pada rak pemeliharaan yang potensil sebagai sumber infeksi. Pada tingkat petani bermanfaat untuk mengetahui perlakuan apa kurang diperhatikan oleh petani di saat pemeliharaan berlangsung. Menurut Bebitha et al. (2016), Pemeliharaan ulatsutera yang berlangsung secara terus menerus dengan periode yang rapat seharusnya disertai pula tindakan preventif disinfeksi yang intensif.

Selain penyakit grasserie yang masih perlu menjadi perhatian adalah penyakit pebrin terutama pada tingkat produsen telur. Studi pola penyebaran kedua penyakit ini penting untuk mengetahui dimana sumber inokulum dan epidemi penyakit. Patogen virus penyebab grasserie selain ditularkan melalui kontaminasi daun murbei, juga dapat melalui permukaan dan progeni telur yang ditularkan dari tetuanya pada saat peletakan telur yang disebut transmisi vertikal (Saez et al., 2014) atau penularannya dari generasi ke generasi (Mahesha 
dan Thejaswini, 2015). Pemahaman pola penyebaran penyakit ulatsutera bagi semua pemangku kepentingan akan dapat terus mempertahankan industri serikultur nasional.

\section{KESIMPULAN}

Tingkat serangan grasserie pada tiga sentra pemeliharaan ulatsutera di Sulawesi Selatan termasuk kategori sangat ringan, kehilangan hasil hanya berkisar 3,06 - 3,72 kg/boks dengan pola penyebaran penyakit seragam.

\section{DAFTAR PUSTAKA}

Andikarya, O. (2007). Kemandirian usaha dengan pola klaster industri sutera alam di Sulawesi Selatan. Makalah yang disajikan pada Temu Usaha Persuteraan Alam Sulawesi Selatan. Tanggal 11-13 Desember 2007 Makassar,1-48.

Anwar, A.. (1985). Laporan kegiatan Seksi Hama dan Penyakit 1983/1984. Proyek Kerjasama Pembinaan Alam. ATA - 72. Japan International Cooperation Agency, 34 - 37.

Atmosoedarjo, S., J. Kartasubrata, M. Kaomini, W. Saleh, W. Moerdoko, Pramoedibyo dan S. Ranoeprawiro. (2000). Sutera Alam Indonesia. Jakarta: Yayasan Sarana Wana Jaya,132-133.

Bebitha, B., P. Mohanraji, S. Manimegalai and C.A. Mahalingam. (2016). Silkworm disease diagnosis through molecular approach and their management. Internat. J. Plant Protec., 9(1), 343-352. DOI: 10.15740/HAS/IJPP/9.1/343-352.

Babu, S.M., G. Gopalaswamy and N. Chandramohan. (2005). Identification of an antiviral principle in Spirulina platensis against Bombyx mori Nuclear Polyhedrosis Virus (BmNPV). Indian Journal of Biotechnology. 4: 384-388.

Chakrabarty, S., S. Deb, A..K. Saha, N. Hazra, B. Manna and B. Bindroo. (2012). Dimorphisim in Nuclear Polyhedrosis Virus (BmNPV) (Family: Baculoviridae) causing 'grasserie' disease in silkworm (Bombyx mori L.): light and electron microscopy and protein profile. Applied Biological Research, 14 (2), 176-186.

Gani, M., S. Chouhan, Babulal, R.K. Gupta, G. Khan, N.B. Kumar, P. Saini and M.K. Ghosh. (2017). Bombyx mori nucleopolyhedrovirus (BmNPV): Its impact on silkworm rearing and management strategies. Journal of Biological Control, 31(4): 189-193, DOI: 10.18311/jbc/2017/16269.

Guo-Ping, K and G. Xi-Jie. (2011). Overview of silkworm pathology in China. African Journal of Biotechnology, 10(79), 18046-18056.

Jiang, L. and Xia, Q. (2014). The progress and future of enhancing antiviral capacity by transgenic technology in the silkworm Bombyx mori. Insect Biochemistry and Molecular Biology, 1-7. Doi.org/10.1016/j.ibmb.2014.02.003.

Kaewwises, M. (2006). Potential application of PCR-Based method for early detection of grasserie disease of silkworm, Bombyx mori. Thesis. Graduate School, Kasetsart University,119. 
Mahalingam C.A., Murugesh K.A. and R. Shanmugam. (2010). Grasserie Disease Incidence on Silkworm and Development of Botanical Based Management Strategy. Indian Journals. Com, 3(2), 212-215.

Mahesha, H.B. and P.H. Thejaswini. (2015). Effects of induced tolerance against nuclear polyhedrosis on economic characters of silkworm Bombyx mori L. and their inheritance. IJBPAS, 4(6), 3997-4006.

Mishra, S.A. (2017). Diseases of silk warm (Bombyx mori) and protocol for treatment. International Journal of Zoology Studies, 2(6), 116-118.

Nuraeni, S. (2017). Gaps in the thread: Disease, production, and opportunity in the failing silk industry of South Sulawesi. Forest and Society, 1(2), 110-120. doi:http://dx.doi.org/10.24259/fs.v1i2.1861

Pielou, E.C. (1977). Mathematical Ecology. John Wiley \& Sons. New York. 385 p.

Potrich, M., L.F.A. Alves, R.C. Brancalhão, and G. Dalcin. (2007). Entomopatógenos associados a lagartas de Bombyx mori L. (Lepidoptera: Bombycidae) no estado do Paraná. São Paulo: Arq. Inst. Biol, 74(4), 363-367.

Saez, C.R.N., R.E.F. Munhoz, N.C. Pereira, T.S. Bignotto, V.A. Fassina, G.M. Pessini, L.B. Garay, L.F.C. Ribeiro, R.M.C. Brancalhão and M.A. Fernandez. (2014). Detection of Contamination and Analysis of Vertical Transmission of BmNPV in Eggs and Moths of Bombyx mori. Open Journal of Genetics, 4, 370-377.

Sharma, R., N.A., Ganie, Z. H. Rufaie, I.L. Khan and J. Parkash. (2014). Screening of various bivoltine hybrids of silkworm Bombyx mori L. for disease susceptibility during monsoon season in Uttar Pradesh. I.J.A.B.R, 4(3), 352-356.

Subbaiah, E.V., C. Royer, S. Kanginakudru, V.V. Satyavathi, A.S. Babu, V. Sivaprasad, G. Chavancy, M. DaRocha, A. Jalabert, B. Mauchamp, I. Basha, P. Couble, and J. Nagaraju. (2012). Engineering silkworms for resistance to baculovirus through multigene RNA interference Genetics: Advance Online Publication, published on October 26, 2012 as 10.1534/genetics.112.144402.

Watanabe, H. (1986). Resistance of the silkworm, Bombyx mori, to viral infections. Agriculture, Ecosystems \& Environment, 15(2), 131-139.

Watanabe, H. (2002). Genetic resistance of the silkworm, Bombyx mori to viral diseases. Current science, 83(4), 439-446.

Yup-lian, L. (1991). Silkworm Disease. Rome: FAO Agricultural Services Bulletin 73/4. p. 75. 